\title{
Diagnostic value of serum procalcitonin level in the diagnosis of the spontaneous bacterial peritonitis
}

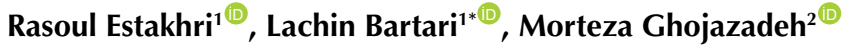 \\ 'Department of Pathology, School of Medicine, Liver and Gastrointestinal Diseases Research Center, Tabriz University of Medical Sciences, \\ Tabriz, Iran \\ ${ }^{2}$ Department of Physiology, Faculty of Medicine, Tabriz University of Medical Sciences, Tabriz, Iran
}

\section{*Correspondence to}

Lachin Bartari,

Email: lachin.bartari.98@

gmail.com,

Bartaril@tbzmed.ac.ir

Received 2 January 2020 Accepted 9 April 2020

Published online 4 May 2020

Keywords: Procalcitonin Spontaneous bacterial peritonitis, Ascites, Cirrhosis, C-reactive protein

\section{Abstract}

Introduction: Spontaneous bacterial peritonitis (SBP) is an infectious ascitic fluid with an unknown intraabdominal source. Rapid diagnosis of infection can improve prognosis in cirrhotic patients.

Objectives: We aim to determine the diagnostic value of serum procalcitonin (PCT) and C-reactive protein (CRP) in SBP.

Patients and Methods: In this cross-sectional study, we included 120 cirrhotic patients with possible diagnosis of SBP asities. Serum and ascitic fluid samples were taken from the patient before initiating antibiotics. The ascitic fluid parameters, serum levels of CRP, PCT and white blood cells were measured and the diagnostic value of the CRP and PCT were evaluated.

Results: Of 120 patients, $59.16 \%$ had confirmed SBP. PCT with a cutoff of $0.8 \mathrm{ng} / \mathrm{mL}$ and CRP with cutoff of $10.5 \mathrm{mg} / \mathrm{L}$ had a sensitivity of $90.91 \%$ and $86.11 \%$ and specificity of $91.5 \%$ and $81.25 \%$ respectively in diagnosing of SBP. Considering PCT above $0.8 \mathrm{ng} / \mathrm{mL}$ and CRP above $10.5 \mathrm{mg} / \mathrm{L}$ both, they had the sensitivity and specificity of $96.87 \%$ and $83.92 \%$ in detecting SBP in cirrhotic patients.

Conclusion: Serum PCT and CRP levels could predict SBP in cirrhotic patients while PCT had the most sensitivity and specificity. Considering both parameters, the sensitivity will increase, but the specificity is decreasing. Both PCT and CRP levels could be used as a less invasive method compared to ascites fluid analysis in diagnosing SBP.

\section{Introduction}

Spontaneous bacterial peritonitis (SBP) is a serious complication in cirrhotic patients $(1,2)$ with a prevalence rate of $10 \%-30 \%$ (3). Mortality rate has been increased by four times in these patients with bacterial infection (4). SBP is associated with poor prognosis and high hospitalization time (5-8).

Early diagnosis of SBP can improve the prognosis (6) since it is difficult to treat in decompensated cirrhotic patients due to mismatch clinical symptoms and biochemical parameters of ascites (9).

According to the guidelines, the gold standard method for SBP diagnosis is ascites culture positivity for bacterial pathogen and polymorphonuclear cells (PMN) count $>250$ cells/ $\mu \mathrm{L}$. However, SBP is not confirmed in $60 \%$ of patients with SBP symptoms and high PMN count in ascites $(2,10)$. Hypersplenism (11) or hepatic encephalopathy (12) cause leukocytosis, which can mask the symptoms and is the certain specific problem in diagnosis

\section{Key point}

In a cross-sectional study on 120 cirrhotic patients with primary diagnosis of spontaneous bacterial peritonitis (SBP), we found serum procalcitonin and C-reactive protein levels could predict SBP.

of SBP. Paracentesis will not be necessary if the serum biological marker is found to detect SBP (10).

Procalcitonin (PCT) is a precursor of calcitonin that secreted from thyroidal and extra-thyroidal tissues and is a new and suitable marker to diagnose bacterial infection. Bacterial infection induces PCT gene expression then PCT secretes in various tissues (13). Several studies were performed on the accuracy of PCT to diagnose SBP.

\section{Objectives}

In this study we aimed to evaluate the value of serum PCT detection in the diagnosis of SBP in cirrhotic patients.

\footnotetext{
Copyright (C) 2020 The Author(s); Published by Nickan Research Institute. This is an open-access article distributed under the terms of the Creative Commons Attribution License (http://creativecommons.org/licenses/by/4.0), which permits unrestricted use, distribution, and reproduction in any medium, provided the original work is properly cited.
} 


\section{Patients and Methods}

\section{Participants and procedure}

In this cross-sectional study, 120 cirrhotic patients with the primary diagnosis of SBP who were admitted in Imam Reza and Sina hospitals, Tabriz, Iran (March 2015 to March 2016), were included. Inclusion criteria included SBP since patients with hypertension, heart failure, diabetes, autoimmune disease, receiving prophylactic antibiotics, receiving immunosuppressant drugs and sepsis due to other bacterial infections were excluded.

Diagnostic paracentesis of ascitic fluid was performed and sent for analysis. According to the results, patients were divided into two groups of confirmed SBP and nonSBP. Patients were considered as: (1) SBP if ascitic analysis showed $\mathrm{PMN} \geq 250$ cells/ $\mu \mathrm{L}$, positive culture or both, (2) non-SBP if none of these criteria was documented.

Sampling was performed before antibiotic administration. Samples of ascitic fluid were taken under complete aseptic conditions and were sent for leukocyte count, biochemical analysis (glucose, protein and $\mathrm{LDH}$ ) and ascites fluid culture. At the same time, serum samples were taken for measurement of leukocyte count, glucose, CRP and PCT. PCT were measured by enzyme-linked immunosorbent assay (ELISA) technique using human PCT ELISA kit (Rosh Inc., USA) and Cobas E 411 analyzer. Laboratory tests were compared between the two groups.

\section{Ethical issues}

The ethics committee of Tabriz University of Medical Sciences approved the study protocol (IR.TBZMED. REC.1395.548). The study was conducted according to the 1964 Helsinki Declaration and its later amendments. All participants gave written informed consent. This paper is the result of pathology residency thesis of Lachin Brtari at this university.

\section{Statistical analysis}

All data were analyzed using SPSS software (version 23; SPSS Inc., Chicago, IL). The results are expressed as Mean \pm standard deviation or percentage. KolmogorovSmirnov test was used to assess normal distribution of data. Chi-square test, Fischer's exact test, independent $t$ test or Mann-Whitney U test were used to compare data between groups. Receiver operating characteristic (ROC) analysis was used to compute the sensitivity, specificity, positive predictive value and negative predictive value. Accordingly, $P<0.05$ was considered significant.

\section{Results}

Of 120 patients, $61(50.8 \%)$ patients were female with mean age of $56.43 \pm 16.28$ years. SBP was found in 71 patients $(59.16 \%)$. Ascites fluid culture was positive in 33 cases $(27.5 \%)$ with $E$. coli as the most common pathogen (33.3\%). There was no difference between patients with and without SBP regarding age and gender (Table 1). SBP patients had significantly higher ascitic protein, PMN and LDH and lower ascitic glucose levels. The PCT and CRP levels were also significantly higher in SBP patients (Table 1).

Accordingly, the receiver operating characteristic (ROC) curve analysis showed that the ascites PMN (AUC: 0.840, $P=0.001$ ), $\mathrm{PMN}$ percentages [AUC (area under the curve); 0.955, P: 0.001)], serum PCT (AUC: 0.972, $P=0.001$ ), and CRP (AUC: $0.898, P=0.001$ ) were all able to predict SBP (Figures 1 and 2).

Table 2 demonstrates the diagnostic values of PMN, PMN percentages, serum PCT and CRP in predicting SBP. Ascitic PMN and serum PCT had the highest sensitivity, while only the specificity for PCT was higher. CRP alone had lower sensitivity and specificity compared to other parameters.

Considering PCT above $0.8 \mathrm{ng} / \mathrm{mL}$ and CRP above 10.5 $\mathrm{mg} / \mathrm{L}$ together, they could detect SBP with sensitivity and specificity of $96.87 \%$ and $83.92 \%$, respectively.

\section{Discussion}

SBP, a severe complication in cirrhotic patients, is usually considered as ascites fluid infection without other contagious sources $(11,14)$. Since the 1970 s, when SBP was described for the first time, its mortality rate declined from $80 \%$ to $30 \%$ due to early diagnosis and appropriate antibiotic treatment $(15,16)$. An acceptable method for SBP diagnosis is ascitic fluid paracentesis and PMN measurement or culture. PMN counts $\geq 250 / \mu \mathrm{L}$ in ascites has been adopted as a diagnostic criterion of SBP, even if the culture is negative for bacteria $(7,17,18)$.

Several markers have been investigated for ascitic fluid infection such as CRP, PCT and PMN $(19,20)$. According to studies, various reports have been published about the

Table 1. Demographic data and laboratory findings in patients

\begin{tabular}{lccc}
\hline Variable & SBP & Without SBP & P value \\
\hline Age & $55.54 \pm 17.44$ & $57.86 \pm 14.5$ & 0.48 \\
Gender & & & 0.13 \\
Male & $36(54.5 \%)$ & $23(42.6 \%)$ & \\
Female & $30(45.5 \%)$ & $31(57.4 \%)$ & \\
Ascites analysis & & & \\
Glucose (mg/dL) & $110.69 \pm 31.14$ & $136.31 \pm 42.91$ & $0.001^{*}$ \\
Protein (g/dL) & $2.21 \pm 1.12$ & $1.72 \pm 1.12$ & $0.02^{*}$ \\
PMN (cells/ $\mathrm{LL})$ & $515.19 \pm 505.83$ & $173.04 \pm 30.81$ & $0.001^{*}$ \\
PMN (percentage) & $78.37 \pm 12.21$ & $39.29 \pm 19.76$ & $0.001^{*}$ \\
LDH & $400.32 \pm 54.3$ & $242.94 \pm 53.94$ & $0.04^{*}$ \\
Serum analysis & & & \\
WBC (cells/mL) & $11771.21 \pm 7156.65$ & $9846.30 \pm 6157.76$ & 0.12 \\
Glucose (mg/dL) & $134.54 \pm 76.76$ & $139.27 \pm 62.93$ & 0.72 \\
Procalcitonin (ng/mL) & $6.98 \pm 5.39$ & $0.53 \pm 0.09$ & $0.001^{*}$ \\
CRP (mg/L) & $22.63 \pm 12.21$ & $8.63 \pm 4.24$ & $0.001^{*}$ \\
\hline SBP Spontaneous & & & \\
\hline
\end{tabular}

SBP, Spontaneous bacterial peritonitis; PMN, polymorphonuclear; LDH, Lactate dehydrogenase. 


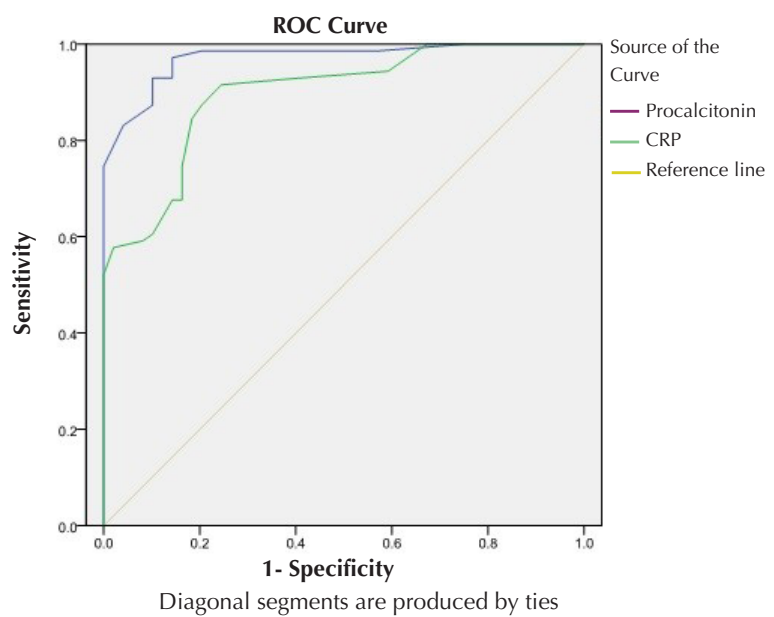

Figure 1. Receiver operating characteristic curves of serum procalcitonin, CRP in detecting SBP.

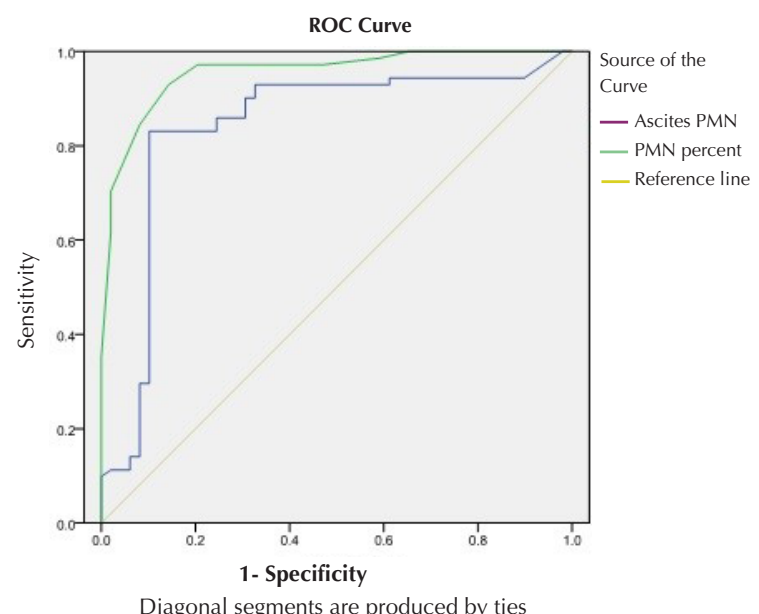

Figure 2. Receiver operating characteristic curves of ascites PMN and PMN percentage in detecting SBP.

Table 2. Diagnostic value of variables in predicting SBP

\begin{tabular}{lcclll}
\hline Variable & Cutoff & Sensitivity & Specificity & NPV & PPV \\
\hline PMN percentage & 62.5 & $90.54 \%$ & $91.30 \%$ & $85.71 \%$ & $94.37 \%$ \\
\hline PMN (cells/ $\mu \mathrm{L})$ & 252 & $92.12 \%$ & $78.57 \%$ & $89.80 \%$ & $83.1 \%$ \\
$\begin{array}{l}\text { Procalcitonin } \\
(\mathrm{ng} / \mathrm{mL})\end{array}$ & 0.8 & $90.91 \%$ & $91.50 \%$ & $84.78 \%$ & $93.59 \%$ \\
\hline CRP $(\mathrm{mg} / \mathrm{L})$ & 10.5 & $86.11 \%$ & $81.25 \%$ & $79.59 \%$ & $87.32 \%$ \\
\hline
\end{tabular}

$\mathrm{NPV}$, negative predictive value; PPV, positive predictive value.

diagnostic value of these tests (21).

Our study demonstrated that PCT with a cutoff value of $0.8 \mathrm{ng} / \mathrm{mL}$ had a sensitivity of $90.91 \%$ and specificity of $91.50 \%$. Abdel-Razik et al (3) reported a high sensitivity and specificity for PCT above $0.94 \mathrm{ng} / \mathrm{mL}$ in diagnosing SBP. Wu et al (22) reported low sensitivity $(77.5 \%)$ and specificity $(60.4 \%)$ with a similar cut-off value of PCT.
While, Hamed et al (23) reported the cut-off value of serum PCT in SBP was $0.495 \mathrm{ng} / \mathrm{mL}$ with sensitivity and specificity of $90 \%$ and $92 \%$, respectively (23).

In general, in various studies, different amounts of cutoff value of PCT $0.38 \mathrm{ng} / \mathrm{mL}$ to $0.94 \mathrm{ng} / \mathrm{mL}$ have been reported with different sensitivities and specificities, and a standard cutoff has not been reported, yet (22, 24-26).

CRP, an acute phase protein, is synthesized by the liver and secreted into the blood plasma within hours in response to the tissue damage, infection and inflammation $(27,23)$.

According to our study, serum CRP with the cutoff value of $10.5 \mathrm{mg} / \mathrm{L}$ had the sensitivity and specificity of $86.11 \%$ and $81.25 \%$, respectively. Different studies have demonstrated similar results $(22,26)$. Hamed et al $(23)$ demonstrated the same cutoff value for CRP with a higher sensitivity (91\%) and specificity (97\%). Additionally, Metwally et al (27) indicated a sensitivity and specificity of $86.4 \%$ and $66 \%$ for CRP $>13.5 \mathrm{mg} / \mathrm{L}$. A cut-off value of 35 $\mathrm{mg} / \mathrm{L}$ was also reported by Sood and colleagues (28).

In the present study, results showed that PMN and PMN percentage with a cutoff value of 252 cells $/ \mathrm{ml}$ and $62.5 \%$, respectively, had a sensitivity of $92.12 \%$ and $90.54 \%$, and the specificity of $78.57 \%$ and $91.30 \%$, respectively. Wang et al (24) reported at a cutoff value of $75.0 \%$ in PMN percentage, the sensitivity and specificity would be $83.03 \%$ and $92.7 \%$, respectively. According to the study by AbdelRazik et al (3) PMN at a cut-off point $265 / \mathrm{mm}^{3}$ could predict SBP with a sensitivity of $91 \%$ and specificity of $73.8 \%$.

\section{Conclusion}

Serum levels of PCT and CRP could predict SBP in cirrhotic patients with PCT having the most sensitivity and specificity. Considering both parameters, the sensitivity will increase, but the specificity is decreasing. Both PCT and CRP levels could be used as a less invasive method compared to ascites fluid analysis in diagnosing SBP.

\section{Limitations of the study}

The small sample of the patients and single-center study were the limitations of the current study.

\section{Ethical considerations}

Ethical issues including plagiarism and double publication have been completely observed by the authors.

\section{Conflicts of interest}

We have no conflicts of interest.

\section{Funding/Support}

The authors received specific funding/support for this work from Liver and Gastrointestinal Diseases Research Center, Tabriz University of Medical Science, Tabriz, Iran.

\section{References}

1. Piano S, Fasolato S, Salinas F, Romano A, Tonon M, Morando 
$\mathrm{F}$, et al. The empirical antibiotic treatment of nosocomial spontaneous bacterial peritonitis: Results of a randomized, controlled clinical trial. Hepatology. 2016;63:1299-309. doi: 10.1002/hep.27941.

2. Yang Y, Li L, Qu C, Zeng B. Diagnostic Accuracy of Serum Procalcitonin for Spontaneous Bacterial Peritonitis Due to Endstage Liver Disease A Meta-analysis. Medicine (Baltimore). 2015;94:e2077. doi: 10.1097/MD.0000000000002077.

3. Abdel-Razik A, Mousa N, Elhammady D, Elhelaly R, Elzehery R, Elbaz S, et al. Ascitic Fluid Calprotectin and Serum Procalcitonin as Accurate Diagnostic Markers for Spontaneous Bacterial Peritonitis. Gut Liver. 2016;10:624-31. doi: 10.5009/ gnl15120.

4. Lutz P, Nischalke HD, Strassburg CP, Spengler U. Spontaneous bacterial peritonitis: The clinical challenge of a leaky gut and a cirrhotic liver. World J Hepatol. 2015;7:304-14. doi: 10.4254/ wjh.v7.i3.304.

5. Karvellas C, Abraldes J, Arabi Y, Kumar A. Appropriate and timely antimicrobial therapy in cirrhotic patients with spontaneous bacterial peritonitis-associated septic shock: a retrospective cohort study. Aliment Pharmacol Ther. 2015;41:747-57. doi: 10.1111/apt.13135

6. Sagar KV, Reddy PR, Chandrasekhar S, Harish D.A clinical study of spontaneous bacterial peritonitis in cirrhosis of liver with ascites in teritiary care hospital. J Evid Based Med Healthc 2016;3:36-41. doi: 10.18410/jebmh/2016/8

7. Cai Z, Fan CL, Zheng JF, Zhang X, Zhao WM, Li B, et al. Measurement of serum procalcitonin levels for the early diagnosis of spontaneous bacterial peritonitis in patients with decompensated liver cirrhosis. BMC Infect Dis. 2015;15:55. doi: 10.1186/s12879-015-0776-4.

8. Thévenot T, Bureau C, Oberti F, Anty R, Louvet A, Plessier A, et al. Effect of albumin in cirrhotic patients with infection other than spontaneous bacterial peritonitis. A randomized trial. J Hepatol. 2015;62:822-30. doi: 10.1016/j.jhep.2014.11.017.

9. Runyon B. Spontaneous bacterial peritonitis: Treatment and prophylaxis. Available from: https://www.uptodate. com/contents/spontaneous-bacterial-peritonitis-in-adultstreatment-and-prophylaxis. 2017.

10. Kim JJ, Tsukamoto MM, Mathur AK, Ghomri YM, Hou LA, Sheibani S, et al. Delayed paracentesis is associated with increased in-hospital mortality in patients with spontaneous bacterial peritonitis. Am J Gastroenterol. 2014;109:1436-42. doi: 10.1038/ajg.2014.212.

11. Fiore M, Maraolo AE, Gentile I, Borgia G, Leone S, Sansone P, et al. Nosocomial spontaneous bacterial peritonitis antibiotic treatment in the era of multi-drug resistance pathogens: A systematic review. World J Gastroenterol. 2017; 23:4654-60.

12. Schwabl P, Bucsics T, Soucek K, Mandorfer M, Bota S, Blacky A, et al. Risk factors for development of spontaneous bacterial peritonitis and subsequent mortality in cirrhotic patients with ascites. Liver Int. 2015;35:2121-8. doi: 10.1111/liv.12795.

13. Friedrich K, Nüssle S, Rehlen T, Stremmel W, Mischnik A, Eisenbach C. Microbiology and resistance in first episodes of spontaneous bacterial peritonitis: implications for management and prognosis. J Gastroenterol Hepatol. 2016;31:1191-5. doi: 10.1111/jgh.13266.

14. Saqib A, Khan RR, Masood Z, Haque I. Frequency of spontaneous bacterial peritonitis (SBP) in cirrhotic patients with ascites due to hepatitis B and C. JUMDC. 2012;3:22-6.
15. Gaduputi V, Tariq H, Chandrala C, Sakam S, Abbas N, Chilimuri S. Computerized tomography-guided paracentesis: an effective alternative to bedside paracentesis? J Clin Med Res. 2017;9: 92-7. doi: 10.14740/jocmr2832w

16. Syed VA, Ansari JA, Karki P, Regmi M, Khanal B. Spontaneous bacterial peritonitis (SBP) in cirrhotic ascites: a prospective study in a tertiary care hospital, Nepal. Kathmandu Univ Med J. 2007;5:48-59

17. Wu C-J, Lee H-C, Chang T-T, Chen C-Y, Lee N-Y, Chang C-M, et al. Aeromonas spontaneous bacterial peritonitis: a highly fatal infectious disease in patients with advanced liver cirrhosis. J Formos Med Assoc. 2009;108:293-300. doi: 10.1016/S09296646(09)60069-3.

18. Mo S, Bendtsen F, Wiese SS, Kimer N. Low ascitic fluid total protein levels is not associated to the development of spontaneous bacterial peritonitis in a cohort of 274 patients with cirrhosis. Scand J Gastroenterol. 2018;53:200-205. doi: 10.1080/00365521.2017.1411973.

19. Cekin Y, Cekin AH, Duman A, Yilmaz U, Yesil B, Yolcular BO. The role of serum procalcitonin levels in predicting ascitic fluid infection in hospitalized cirrhotic and non-cirrhotic patients. Int J Med Sci. 2013;10:1367-74. doi: 10.7150/ijms.6014.

20. Yuan LY, Ke ZQ, Wang M, Li Y. Procalcitonin and C-reactive protein in the diagnosis and prediction of spontaneous bacterial peritonitis associated with chronic severe hepatitis B. Ann Lab Med. 2013;33:449-54. doi: 10.3343/alm.2013.33.6.449.

21. Pieri G, Agarwal B, Burroughs AK. C-reactive protein and bacterial infection in cirrhosis. Ann Gastroenterol. 2014; 27:113-20.

22. Wu H, Chen L, Sun Y, Meng C, Hou W. The role of serum procalcitonin and $\mathrm{C}$-reactive protein levels in predicting spontaneous bacterial peritonitis in patients with advanced liver cirrhosis. Pak J Med Sci. 2016;32:1484-8. doi: 10.12669/ pjms.326.10995

23. Hamed M, Hakim H, El-Masshad N, Eskandere D. Serum procalcitonin and c-reactive protein in prediction of spontaneous bacterial peritonitis. GHJ 2017;1:20-3.

24. Wang Y, Zhang Y, Zhu JY, Sun LI, Xie SB. Value of Serum procalcitonin and percentage of neutrophils in early diagnosis of bacterial infection in decompensated liver cirrhosis. Journal of Sun Yat-sen University. 2018;39: 413-9.

25. Hua Y, Zhao C, Li M, Jin Y, Zhao Y, Wang $H$. The significance of serum procalcitonin and C-reactive protein in the diagnosis of spontaneous bacterial peritonitis in patients with liver cirrhosis combined with ascites. Chinese Journal of Postgraduates of Medicine. 2017;40:986-9

26. Wu X, Wang Y, Luo H, Liu L. Diagnosis value of PCT in patients with liver cirrhoses complicating spontaneous bacterial peritonitis analyzed by ROC curve. International Journal of Laboratory Medicine. 2016;37:1928-9.

27. Metwally K, Fouad T, Assem M, Abdelsameea E, Yousery M. Predictors of Spontaneous Bacterial Peritonitis in Patients with Cirrhotic Ascites. J Clin Transl Hepatol. 2018;6:372-6. doi: 10.14218/JCTH.2018.00001.

28. Sood V, Lal B, Rawat D, Khanna R, Alam S. Elevated C-Reactive Protein and Spontaneous Bacterial Peritonitis in Chronic Liver Disease and Ascites. J Pediatr Gastroenterol Nutr. 2014;59:e15. doi: 10.1097/MPG.0000000000000396. 